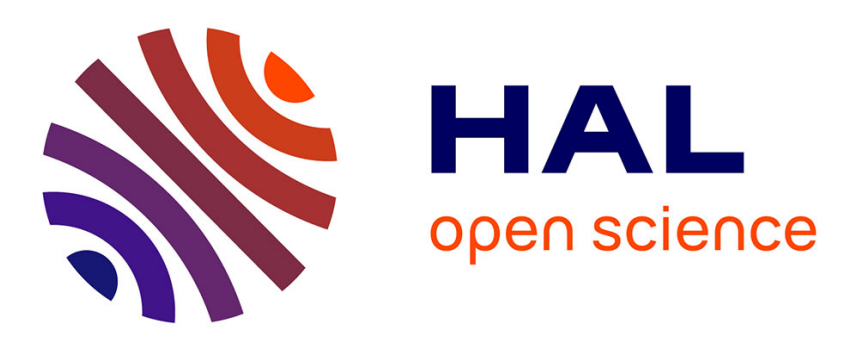

\title{
CF2H as hydrogen bond donor group for the fine tuning of peptide bond geometry with difluoromethylated pseudoprolines
}

N Malquin, K Rahgoshay, N Lensen, G Chaume, E Miclet, Thierry Brigaud

\section{- To cite this version:}

N Malquin, K Rahgoshay, N Lensen, G Chaume, E Miclet, et al.. CF2H as hydrogen bond donor group for the fine tuning of peptide bond geometry with difluoromethylated pseudoprolines. Chemical Communications, 2019, 55 (83), pp.12487-12490. 10.1039/C9CC05771D . hal-03549249

\author{
HAL Id: hal-03549249 \\ https://hal.science/hal-03549249
}

Submitted on 31 Jan 2022

HAL is a multi-disciplinary open access archive for the deposit and dissemination of scientific research documents, whether they are published or not. The documents may come from teaching and research institutions in France or abroad, or from public or private research centers.
L'archive ouverte pluridisciplinaire HAL, est destinée au dépôt et à la diffusion de documents scientifiques de niveau recherche, publiés ou non, émanant des établissements d'enseignement et de recherche français ou étrangers, des laboratoires publics ou privés. 


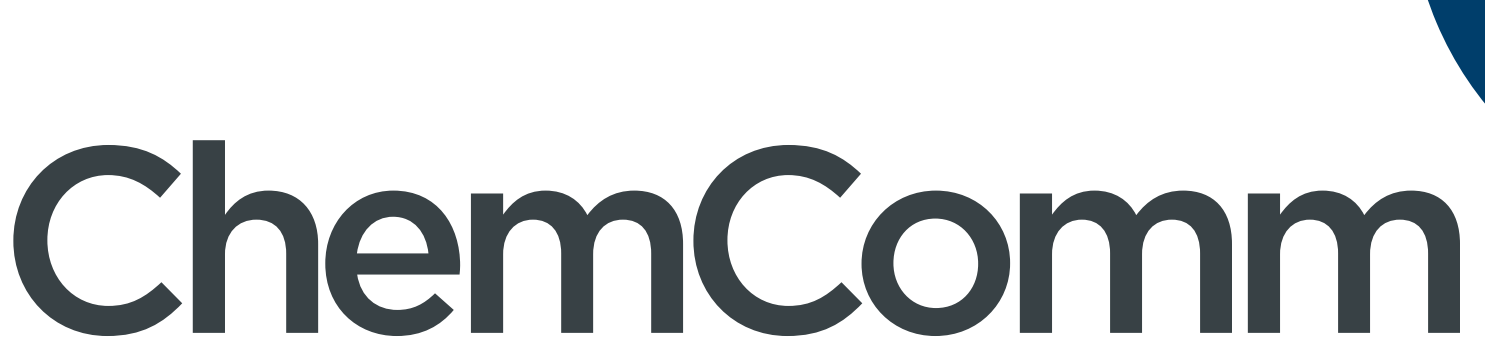

Chemical Communications

\section{Accepted Manuscript}

This article can be cited before page numbers have been issued, to do this please use: N. Malquin, K. Rahgoshay, N. Lensen, G. Chaume, E. Miclet and T. Brigaud, Chem. Commun., 2019, DOI:

10.1039/C9CC05771D.
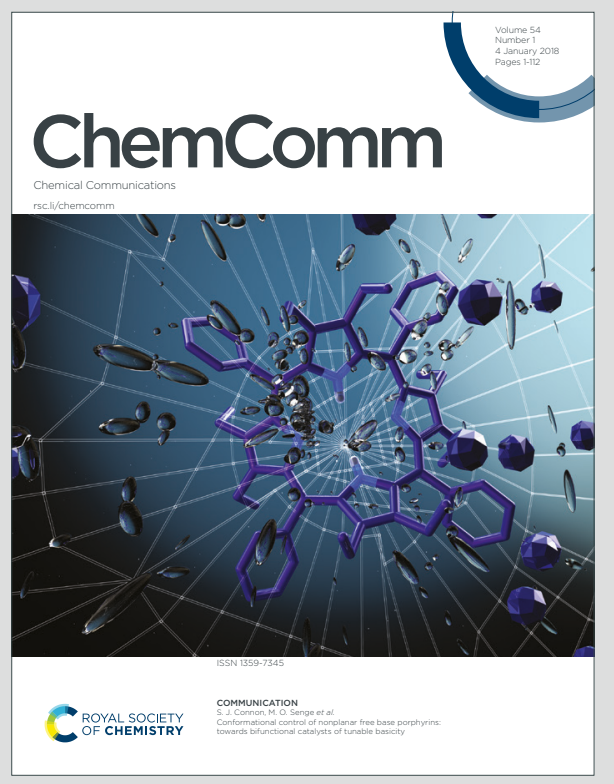

This is an Accepted Manuscript, which has been through the Royal Society of Chemistry peer review process and has been accepted for publication.

Accepted Manuscripts are published online shortly after acceptance, before technical editing, formatting and proof reading. Using this free service, authors can make their results available to the community, in citable form, before we publish the edited article. We will replace this Accepted Manuscript with the edited and formatted Advance Article as soon as it is available.

You can find more information about Accepted Manuscripts in the Information for Authors.

Please note that technical editing may introduce minor changes to the text and/or graphics, which may alter content. The journal's standard Terms \& Conditions and the Ethical guidelines still apply. In no event shall the Royal Society of Chemistry be held responsible for any errors or omissions in this Accepted Manuscript or any consequences arising from the use of any information it contains. 
Received 00th January 20xx, Accepted 00th January 20xx

\section{$\mathrm{CF}_{2} \mathrm{H}$ as hydrogen bond donor group for the fine tuning of peptide bond geometry with difluoromethylated pseudoprolines}

\author{
N. Malquin, ${ }^{a}$ K. Rahgoshay, ${ }^{a}$ N. Lensen, ${ }^{* a}$ G. Chaume, ${ }^{* a}$ E. Miclet ${ }^{b}$ and T. Brigaud*a
}

DOI: $10.1039 / x 0 x \times 00000 x$

\begin{abstract}
$\mathrm{CF}_{2} \mathrm{H}$-pseudoprolines obtained from difluoroacetaldehyde hemiacetal and serine are stable proline surrogates. The consequence of the incorporation of the $\mathrm{CF}_{2} \mathrm{H}$ group is an important decrease of the trans to cis amide bond isomerisation energy and a remarkable stabilisation of the cis conformer by an hydrogen bond.
\end{abstract}

Because of the unique properties of fluorine atom, fluorinated compounds are increasingly recognized as highly promising for the discovery of new bioactive compounds. ${ }^{1}$ Considering the specific case of peptides, the incorporation of fluorinated amino acids in peptides has been shown to impart remarkable properties. $^{2}$ It can modulate the peptide conformation and assembly, $^{3}$ the local hydrophobicity, ${ }^{2,4}$ and the resistance towards proteolysis. ${ }^{5}$ Moreover fluorine atoms are very useful as highly sensitive labels for ${ }^{19} \mathrm{~F}-\mathrm{NMR}$ spectroscopy because of ${ }^{19} \mathrm{~F} 100 \%$ natural abundance and the absence of background signals in natural and biological media. ${ }^{6}$ Although several methods have been reported for the synthesis of trifluoromethylated amino acids, the preparation of difluoromethylated one's is much less common. ${ }^{2,7}$ It is a lack because the $\mathrm{CF}_{2} \mathrm{H}$ group presents unique features and we believe that this group will play an increasing role in peptides chemistry. The main property of the $\mathrm{CF}_{2} \mathrm{H}$ group is to act as a lipophilic hydrogen bond donor group bioisostere of a hydroxyl or a thiol. ${ }^{8}$ These original bioisosteric properties have recently been highlighted in medicinal chemistry. ${ }^{9}$ Because of its cyclic structure, the proline residue is recognized to play a unique and crucial role on peptide backbone conformation. When included into a peptide, the pyrrolidine ring cannot act as an hydrogen bond donor and restrain the $\phi$ diehedral angle to about $-60^{\circ} .^{10}$ The Xaa-Pro peptide bond is characterized by a small free energy difference $\left(\Delta \mathrm{G}^{\circ}{ }_{\mathrm{tc}}\right)$ between the trans and the

a. Laboratory of Chemical Biology (LCB, EA 4505), Université de Cergy-Pontoise, 5 Mail Gay-Lussac, 95000 Cergy-Pontoise, France.

b. Sorbonne Université, École normale supérieure, PSL University, CNRS, Laboratoire desBiomolécules, 75005 Paris, France.

+ Footnotes relating to the title and/or authors should appear here.

Electronic Supplementary Information (ESI) available: [details of any supplementary information available should be included here]. See DOI: $10.1039 / x 0 x \times 00000 x$ cis amide bond conformers, combined with a high activation energy $\left(\Delta G_{t c}^{\ddagger}\right)$ for the cis-trans isomerization. ${ }^{11}$ This isomerisation is considered to play a key role in regulating many important biological processes in proline containing peptides and proteins, including protein folding. ${ }^{12}$ However, studies of protein folding or control of the peptide or protein function are often hampered by the heterogeneity of the X-Pro peptide bond geometry and the scientific community has constantly been on the lookout for either a cis or a trans stabilizing proline analogue or surrogate. ${ }^{13}$ In the fluorinated series, $\mathrm{CF}_{3}$-substituted prolines have recently emerged as very attracting tools for the control of peptides conformation and hydrophobicity. ${ }^{14}$ On the other hand, very few examples of difluoromethylated prolines have been reported in the literature, ${ }^{15}$ and to our knowledge the synthesis of enantiopure $5-\mathrm{CF}_{2} \mathrm{H}$-prolines has not been reported so far. Pseudoprolines ( $\Psi$ Pro) obtained from the condensation of serine and aldehydes appear as very useful surrogates of $\delta$ substituted prolines to control the conformation of peptides. ${ }^{16}$ Since several years we investigate the scope of trifluoromethylated pseudoprolines ( $\mathrm{CF}_{3}-\Psi$ Pro) in peptide chemistry. ${ }^{17}$ We reported that the ratio of cis conformation of the $\mathrm{Xaa}-\mathrm{CF}_{3}-\Psi$ Pro peptide bond is increased compared to proline itself. The $2-(S)-\mathrm{CF}_{3}-\Psi$ Pro presents a $\gamma$-endo puckering of the oxazolidine ring while the $2-(R)-\mathrm{CF}_{3}-\Psi$ Pro adopts a $\gamma$-exo puckering (Fig. 1). ${ }^{17}$ Moreover, a remarkable feature of the 2$(R)-\mathrm{CF}_{3}-\Psi$ Pro is the decrease of the trans to cis isomerization barrier of the amide bond $\left(-4.17 \mathrm{kcal}^{\mathrm{mol}}{ }^{-1}\right.$ compared to proline). ${ }^{1}$

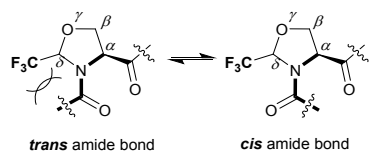

Peptidyl bond isomerization

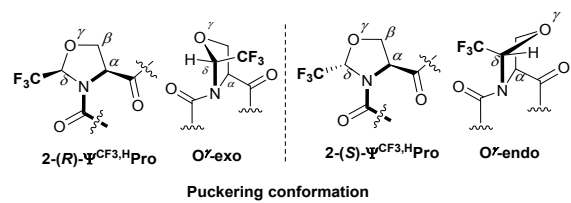

Fig. 1 Peptidyl bond isomerization and puckering of $\mathrm{CF}_{3}-\Psi$ Pro 
COMMUNICATION

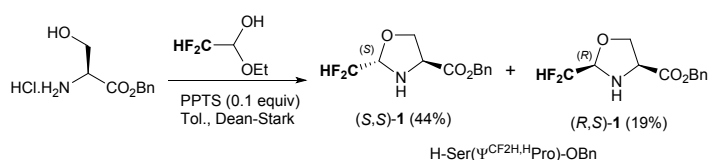

Scheme 1 Synthesis of $\mathrm{H}-\mathrm{Ser}\left(\psi^{\mathrm{CF} 2 \mathrm{H}, \mathrm{H}} \mathrm{PrO}\right)-\mathrm{OBn}(S, S)-\mathbf{1}$ and $(R, S)-\mathbf{1}$

Considering the growing importance of the difluoromethyl group, we wish to present herein our results dedicated to difluoromethylated pseudoprolines $\left(\mathrm{CF}_{2} \mathrm{H}-\Psi\right.$ Pro). A particular attention is paid to the possibility of interactions through hydrogen bonds.

The oxazolidine ring of the $\mathrm{CF}_{2} \mathrm{H}$-pseudoproline was built by condensation of difluoroacetaldehyde ethyl hemiacetal with serine benzyl ester under an acidic catalysis (Scheme 1$)$. Both diastereomers $(S, S)$-1 and $(R, S)$-1 were conveniently separated by silica gel chromatography. According to our previous investigations in the trifluoromethylated series, ${ }^{17 a}$ the cis relative configuration of $(R, S)-\mathbf{1}$ has been assigned by nuclear Overhauser effect experiments showing a correlation between the $\mathrm{C}_{\alpha}$ and the $\mathrm{C}_{\delta}$ protons. In order to investigate the electronic and geometric consequences due to the $\mathrm{CF}_{2} \mathrm{H}$ group incorporation of $\mathrm{CF}_{2} \mathrm{H}-\Psi$ Pro in a peptide chain, the Ac- $\Psi$ ProNHMe model tripeptides $(S, S)-4$ and $(R, S)-4$ have been synthesized in a multi-step procedure (Scheme 2). The $N$ acetylation of $(S, S)-\mathbf{1}$ with acetic anhydride under iodine catalysis provided a mixture of Ac- $\Psi$ Pro-OBn $(S, S)-2(21 \%)$ and $(R, S)-2$ (39\%). In order to circumvent the epimerization of the $\mathrm{C}_{\delta}$ atom through an acidic catalysis, ${ }^{17 a, b}$ the reaction was performed with acetyl chloride in pyridine. These experimental conditions led to the expected $\mathrm{N}$-acetylated oxazolidines $(S, S)$ 2 and $(R, S)-\mathbf{2}$ in $81 \%$ and $75 \%$ yield respectively without epimerisation.

The cis/trans ratio of the acetyl- $\Psi$ Pro bond was determined by ${ }^{1} \mathrm{H}$ and ${ }^{19} \mathrm{~F} \mathrm{NMR}$ integration in $\mathrm{CDCl}_{3}$. For that purpose, we first assigned each conformers by comparing the $\alpha, \beta$, and $\gamma{ }^{13} \mathrm{C}$ chemical shifts of the cis and the trans isomers according to Lubell et al. ${ }^{18 a}$ For the trans isomer, the $\alpha$ and $\beta$-carbons appear upfield while they appear downfield in the cis isomer. Conversely, the $\delta$ carbon for the trans isomer appears downfield relative to that of the cis isomer. Once acetylated on their $N$-terminal position, we checked the acidic stability of the $\mathrm{CF}_{2} \mathrm{H}$-oxazolidines $(S, S)-\mathbf{2}$ and $(R, S)$-2. Experiments showed that, similarly to the $\mathrm{CF}_{3}$ - $\Psi$ Pro, they are stable in an acidic medium (5\% TFA in $\mathrm{CHCl}_{3}$ ), whereas pseudoprolines of the nonfluorinated series are generally prone to ring opening. ${ }^{16 a}$ Even when exposed to more concentrated acidic medium for several hours ( $3 \mathrm{~h}$ in $\mathrm{TFA} / \mathrm{H}_{2} \mathrm{O}$ 95:5) no ring opening or epimerization occurred. The $\mathrm{CF}_{2} \mathrm{H}$-oxazolidines are therefore suitable for SPPS strategy.

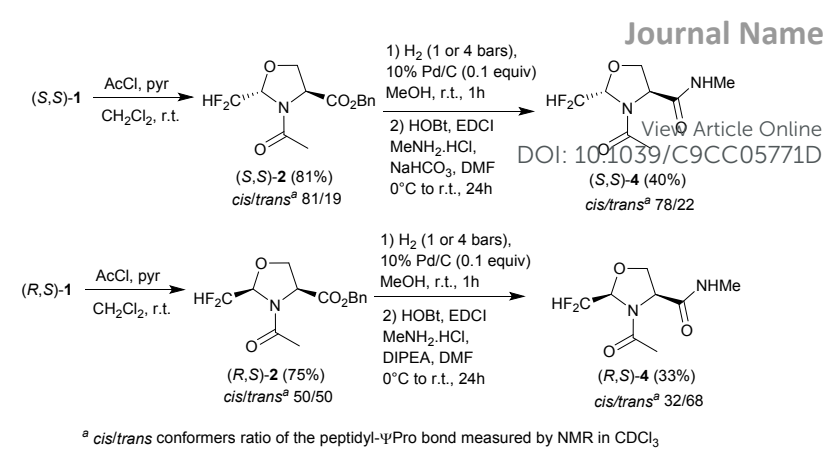

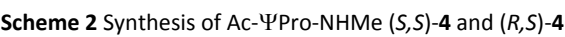

After removal of the benzyl ester function by hydrogenolysis in quantitative yields, the $N$-methyl amides $(S, S)-4$ and $(R, S)-4$ were obtained in $40 \%$ and $33 \%$ yield using classical peptide coupling conditions (Scheme 2).

The cis-trans bond isomerisation of the $\mathrm{CF}_{2} \mathrm{H}$-oxazolidinecontaining peptide models $(S, S)-\mathbf{4}$ and $(R, S)-\mathbf{4}$ was studied by ${ }^{1} \mathrm{H}$ NMR analysis in water at various temperatures. The coalescence temperatures were determined to estimate the rotational barriers for the cis-trans isomerisation. The results are reported in the Table 1 and compared with those reported for regular proline ${ }^{18}$ and pseudoproline ${ }^{17 c}$ as well as those previously obtained in the $\mathrm{CF}_{3}$ series. ${ }^{17 \mathrm{c}}$ The difference of isomerisation energy between the two diastereomers of the $\mathrm{CF}_{3}$ series (ca. $2.5 \mathrm{kcal}^{\mathrm{mol}}{ }^{-1}$ ) is no longer observed in the $\mathrm{CF}_{2} \mathrm{H}$ series, the energy barriers are low for both $\mathrm{CF}_{2} \mathrm{H}$ pseudoprolines. It is interesting to note that the energy barriers for amide isomerisation of both $\mathrm{CF}_{2} \mathrm{H}$-pseudoproline is ca $5.0 \mathrm{kcal} . \mathrm{mol}^{-1}$ lower than for proline. ${ }^{18}$

The cis amide bond contents were significantly higher when the $\mathrm{CF}_{3}$ substituent was replaced by the $\mathrm{CF}_{2} \mathrm{H}$ group. Indeed in the apolar chloroform solution, the cis population of $(S, S)-\mathbf{4}$ reached even $78 \%$. This enrichment may be due to the presence of a new $\mathrm{H}$-bond involving the $\mathrm{CF}_{2} \mathrm{H}$ group. ${ }^{8}$ Conversely, it was previously demonstrated that the trans amide bond conformer of the 2-(R)- $\mathrm{CF}_{3}-\Psi$ Pro analogue was stabilized by a $\mathrm{H}$-bond between the $\mathrm{C}$-terminal amide $\mathrm{NH}$ and the carbonyl of the $N$-terminal acetyl group. ${ }^{17 c}$ Two antagonist $\mathrm{H}$-bonds may thus compete in the compound (R,S)-4 (Fig. 2). This balance was slightly in favour of the $\mathrm{CF}_{2} \mathrm{H} \mathrm{H}$-bond in water (53\% cis population) and underlines the hydrophobicity of the fluorinated group which partially preserves the stability of the $\mathrm{H}$-bond in polar solvents such as methanol and water (see supplementary information).

Finally, the puckerings of the $\mathrm{CF}_{2} \mathrm{H}$-five-membered rings were determined by NMR from the coupling constants between the $\alpha$ and the $\beta$ protons as previously reported in the $\mathrm{CF}_{3}$ series (see supplementary information). ${ }^{17 \mathrm{c}}$

The results showed that the Ac- $(2 S, 4 S)-\mathrm{CF}_{2} \mathrm{H}-\Psi$ Pro-NHMe $(S, S)$ 4 adopted a $\gamma$-endo puckering conformation for the two

Table 1 Thermodynamic properties of $(S, S)-4$ and $(R, S)-4$ determined by NMR. (a) Populations (\%) observed in $\mathrm{CDCl}_{3}$. ${ }^{(b)}$ Populations $(\%)$ and ${ }^{(c)}$ energies observed in $\mathrm{H}_{2} \mathrm{O}: \mathrm{D}_{2} \mathrm{O} 90: 10$. All energies are given in $\mathrm{kcal}_{\text {. } \mathrm{mol}^{-1}}$

\begin{tabular}{|c|c|c|c|c|c|c|}
\hline & Pro & UPro (ref 17c) & $2-(S)-\mathrm{CF}_{3}-\Psi \operatorname{Pro}{ }^{(\operatorname{ref} 17 \mathrm{c})}$ & $\begin{array}{c}2-(S)-\mathrm{CF}_{2} \mathrm{H}-\Psi \text { pro } \\
(S, S)-4\end{array}$ & $\begin{array}{c}2-(R)-\mathrm{CF}_{2} \mathrm{H}-\Psi \text { pro } \\
(R, S)-4\end{array}$ & $2-(R)-\mathrm{CF}_{3}-\Psi$ Pro ${ }^{(\text {ref } 17 c)}$ \\
\hline cis/trans ${ }^{(\mathrm{a})}$ & $13: 87^{\text {(ref 18b) }}$ & $27: 73$ & $40: 60$ & $78: 22$ & $32: 68$ & $24: 76$ \\
\hline$c i s /$ trans $^{(b)}$ & $24: 76$ (ref 18b) & $34: 66$ & $43: 57$ & $60: 40$ & $53: 47$ & $45: 55$ \\
\hline$\Delta \mathrm{G}_{\mathrm{t}-\mathrm{c}}^{\ddagger}(\mathrm{c})$ & 20.40 (ref 18a) & 18.41 & 18.06 & 15.19 & 15.82 & 15.63 \\
\hline$\Delta G_{c-t}^{\ddagger}(c)$ & 19.83 (ref 18a) & 17.93 & 17.88 & 15.45 & 15.90 & 15.51 \\
\hline
\end{tabular}


Journal Name
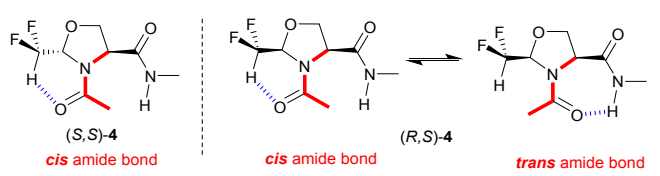

Fig. 2 Possible intramolecular H-bonds for Ac- $\Psi$ Pro-NHMe $(S, S)-\mathbf{4}$ and $(R, S)-\mathbf{4}$

geometries of the peptide bond. The same observation was made for the 2-(S)- $\mathrm{CF}_{3}$ - $\Psi$ Pro analogue. ${ }^{17 c}$ Conversely the compound $(R, S)-4$ underwent a puckering switch when the amide bond geometry was reversed.

Instead of maintaining an exo-puckered oxazolidine ring for both the cis and the trans amide conformers, as observed with 2-(R)- $\mathrm{CF}_{3}-\Psi$ Pro, ${ }^{17 \mathrm{c}}$ the cis rotamer of $(R, S)-\mathbf{4}$ showed a slight preference for the endo puckering to allow the $\mathrm{CF}_{2} \mathrm{H} \mathrm{H}$-bond.

These structural features can be understood by analyzing the unusual NMR parameters of the $\mathrm{CF}_{2} \mathrm{H}$ groups. First, a high chemical shift difference $(\Delta \delta)$ of the diastereotopic ${ }^{19} \mathrm{~F}$ informed about a restricted dynamic of the difluoromethyl group. For the cis conformers, $\Delta \delta$ was above $5 \mathrm{ppm}$, whereas $\Delta \delta \approx 3 \mathrm{ppm}$ for their corresponding trans conformations (see Fig. 3 and supplementary information). Second, the measured vicinal couplings reflected a very limited rotameric averaging of the $\mathrm{CF} 2 \mathrm{H}$ group for the cis conformers. In particular the Ac$(2 S, 4 S)-\mathrm{CF}_{2} \mathrm{H}-\Psi$ Pro-NHMe $(S, S)-4$ displayed the following values: ${ }^{3} J_{\mathrm{H} \delta-\mathrm{F} 1}=3.2 \mathrm{~Hz} ;{ }^{3} J_{\mathrm{H} \delta-\mathrm{F} 2}=18.2 \mathrm{~Hz} ;{ }^{3} J_{\mathrm{H} \varepsilon-\mathrm{H} \delta}=1.0 \mathrm{~Hz}$. These three couplings are compatible with a single $\mathrm{H}^{\varepsilon}-\mathrm{C}^{\varepsilon}-\mathrm{C}^{\delta}-\mathrm{H}^{\delta}$ dihedral angle of $\sim 50^{\circ}$ (see supplementary information). Such a restricted rotation of the $\mathrm{CF}_{2} \mathrm{H}$ group likely arose from the $\mathrm{H}$ bonding observed in the cis forms since the oxygen of the preceding acetyl group is facing the positively charged $\mathrm{CF}_{2} \mathrm{H}$ proton in this conformation (Fig. 3). The endo puckering of the oxazolidine ring may be needed for the $\mathrm{CF}_{2} \mathrm{H}$ H-bonding establishment in the cis conformers, whereas the exo puckering was required for the $\mathrm{NH} . . . \mathrm{O}=\mathrm{C} \mathrm{H}$-bond in the trans form. ${ }^{17 \mathrm{c}}$ This provides an explanation for the trans-exo to cisendo transition observed for the compound $(R, S)-4$. The $(S, S)-4$ diastereoisomer adopts preferentially the endo conformation which explains the high stability of the $\mathrm{CF}_{2} \mathrm{H} \ldots \mathrm{O}=\mathrm{C} \mathrm{H}$-bond in the cis conformer. In the trans conformers, the $\mathrm{CF}_{2} \mathrm{H}$ group cannot establish any $\mathrm{H}$-bond since the $\mathrm{O}=\mathrm{C}$ acceptor of the acetyl is moved away and replaced by the methyl group. As a result, several rotamers of the $\mathrm{CF}_{2} \mathrm{H}$ group are present as attested by the averaged NMR parameters (Fig. 3).

In order to expand the scope of the incorporation of $\mathrm{CF}_{2} \mathrm{H}$ pseudoprolines in peptides, a preliminary methodological study of the peptide coupling reactions at their $N$ - and $C$ position was undertaken. We already demonstrated that the presence of a $\mathrm{CF}_{3}$ group at the $\delta$ position of an oxazolidine unit is detrimental for coupling reactions because of its powerful withdrawing effect. Although the $\mathrm{CF}_{2} \mathrm{H}$ group is less deactivating, typical protocols using $\mathrm{HOBt}, \mathrm{EDCl}$, DIPEA or IBCF reagents failed to achieve the $N$-coupling reaction of $(S, S)$-1 and $(R, S)-1$ with Fmoc-Gly-OH. However, the peptide coupling could be achieved in good yields while using the most electrophilic Fmoc protected glycine and alanine amino acid chloride (Scheme 3). When the reaction was performed in the presence of pyridine, the epimerization of the $\delta$ carbon of the oxazolidine ring through a dynamic kinetic resolution (DKR) process $^{17 \mathrm{~b}}$ was avoided or limited. The expected dipeptides $(S, S)-5,(R, S)-5,(S, S)-6$ and $(R, S)-6$ were obtained in $86 \%, 76 \%$, $57 \%$ and $88 \%$ yield respectively (Scheme 3 ). It should be

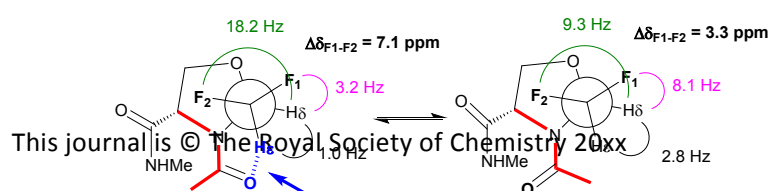

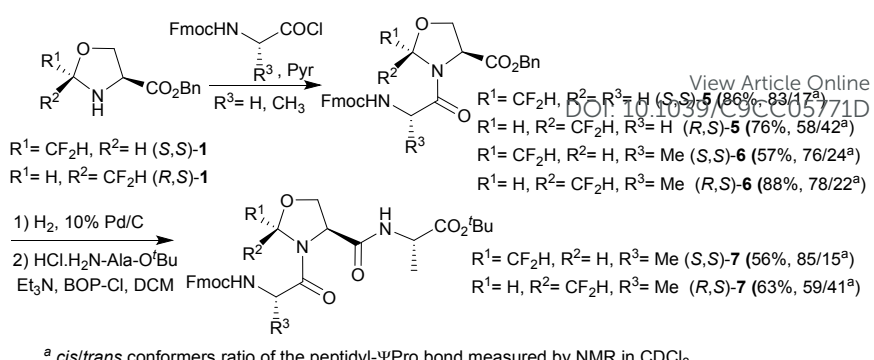

Scheme $\mathbf{3}$ Incorporation of $\mathrm{CF}_{2} \mathrm{H}$-pseudoprolines in a peptide chain

noticed that in any cases the cis conformer of the amide bond was the major one. The cis/trans conformers ratio of the peptidyl- $\Psi$ Pro bond measured by $\mathrm{NMR}$ in $\mathrm{CDCl}_{3}$ were ranging from $58 / 42$ to $83 / 17$. After having successfully solved the challenging coupling reaction at the $\mathrm{N}$-terminal positions of the $\mathrm{CF}_{2} \mathrm{H}$-pseudoprolines, suitable experimental conditions were investigated for the $C$-terminal coupling. The removal of the benzyl ester was carried out by palladium mediated hydrogenolysis without impacting the N-Fmoc protecting group. The free carboxylic acid was then used in the next step without further purification. Typical protocols involving $\mathrm{HOBt}$, $\mathrm{EDCl}$, DIPEA at room temperature were not suitable for the coupling reaction between dipeptides 6 and $\mathrm{HCl}$. $\mathrm{H}_{2} \mathrm{~N}-\mathrm{Ala}-\mathrm{O}^{\mathrm{t}} \mathrm{Bu}$. However, the coupling of the $\mathrm{CF}_{2} \mathrm{H}$-dipeptides using $\mathrm{BOP}-\mathrm{Cl}$ in the presence of TEA afforded the expected tripeptides $(S, S)-7$ and $(R, S)-7$ in $56 \%$ and $63 \%$ yield respectively. ${ }^{19} \mathrm{~F}$ and ${ }^{1} \mathrm{H}$ NMR measurements in $\mathrm{CDCl}_{3}$ revealed a 85/15 cis/trans ratio for $(S, S)$ 7 and $59 / 41$ for $(R, S)-7$.

In conclusion, original enantiopure $(S, S)$ and $(R, S) \quad \mathrm{CF}_{2} \mathrm{H}$ pseudoprolines have been synthesized as stable 5-substituted proline surrogates which can be incorporated in a peptide chain. The $\mathrm{CF}_{2} \mathrm{H}$ group provides a strong decrease of the trans to cis amide bond isomerisation energy and enhances the cis conformation content compared to the $\mathrm{CF}_{3}$ series, by acting as an efficient hydrogen bond donor. These $\mathrm{CF}_{2} \mathrm{H}$-proline surrogates will provide outstanding tools for the fine tuning of the dynamic and the secondary structure of peptides, in particular type VI $\beta$-turns. ${ }^{13 d}$ Such conformations are known to play important roles in protein structures and molecular recognition. New non-natural amino acids able to stabilize the cis-isomer backbone geometry and/or type VI $\beta$-turns are still in demand for the design of potent and selective prototypes for drug discovery. ${ }^{19}$

The authors gratefully acknowledge Central Glass Co. for the gift of difluoroacetaldehyde hemiacetal and the Agence Nationale de la Recherche for funding (ANR CH2PROBE and ANR F-LAIR). K. R. thanks the MNREST for a fellowship.

\section{Conflicts of interest}

There are no conflicts to declare.

\section{Notes and references}

1 (a) S. Purser, P. R. Moore, S. Swallow and V. Gouverneur, Chem. Soc. Rev., 2008, 37, 320; (b) N. A. Meanwell J. Med. Chem., 2018, 61, 5822; (c) E. P. Gillis, K. J. Eastman, M. D. Hill, D. J. Donnelly and N. A. Meanwell, J. Med. Chem., 2015, 58, 8315; (d) W. K. J. Hagmann, J. Med. Chem., 2008, 51, 
4359; (e) J. Wang, M. Sánchez-Roselló, J. L. Aceña, C. del Pozo, A. E. Sorochinsky, S. Fustero, V. A. Soloshonok and H. Liu, Chem. Rev., 2014, 114, 2432; (f) Y. Zhou, J. Wang, Z. Gu, S. Wang, W. Zhu, J.L. Aceña, V. A. Soloshonok, K. Izawa and H. Liu, Chem. Rev., 2016, 116, 422.

2 (a) A. A. Berger, J.-S. Völler, N. Budisa and B. Koksch, Acc. Chem. Res., 2017, 50, 2093; (b) E. N. G. Marsh, Acc. Chem. Res., 2014, 47, 2878; (c) M. Salwiczek, E. K. Nyakatura, U. I. M. Gerling, S. Ye and B. Koksch, Chem. Soc. Rev., 2012, 41 2135.

3 U. I. M. Gerling, M. Salwiczek, C. D. Cadicamo, H. Erdbrink, C. Czekelius, S. L. Grage, P. Wadhwani, A. S. Ulrich, M Behrends, G. Haufe and B. Koksch, Chem. Sci., 2014, 5, 819.

4 (a) C. Gadais, E. Devillers, V. Gasparik, E. Chelain, J. Pytkowicz and T. Brigaud, ChemBioChem, 2018, 19, 1026; (b) J. R. Robalo, S. Huhmann, B. Koksch and A. Vila Verde, Chem, 2017, 3, 881 .

5 (a) S. Huhmann and B. Koksch, Eur. J. Org. Chem., 2018, 3667, (b) V. Asante, J. Mortier, G. Wolber and B. Koksch, Amino Acids, 2014, 46, 2733; (c) G. Akcay and K. Kumar, J. Fluorine Chem., 2009, 130, 1178.

6 For review on the use of ${ }^{19} \mathrm{~F}$ NMR, see: (a) E. N. G. Marsh and Y. Suzuki, ACS Chem. Biol., 2014, 9, 1242; (b) A. Vulpetti and C. Dalvit, Drug Discov. Today, 2012, 17, 890; (c) K. Koch, S. Afonin, M. leronimo, M. Berditsch and A. S. Ulrich, Top. Curr. Chem., 2012, 306, 89; (d) K. E. Arntson and W. C. K. Pomerantz, J. Med. Chem., 2016, 59, 5158.

7 Y.-G. Lou, A.-J. Wang, L. Zhao, L.-F. He, X.-F. Li, C.-Y. He and X. Zhang, Chem. Commun., 2019, 55, 3705.

8 (a) Y. Zafrani, D. Yeffet, G. Sod-Moriah, A. Berliner, D. Amir D. Marciano, E. Gershonov and S. Saphier, J. Med. Chem. 2017, 60, 797; (b) C. D. Sessler, M. Rahm, S. Becker, J. M Goldberg, F. Wang and S. J. Lippard, J. Am. Chem. Soc., 2017, 139, 9325; (c) J. A. Erickson and J. I. McLoughlin, J. Org. Chem., 1995, 60, 1626; (d) Q. A. Huchet, B. Kuhn, B. Wagner, N. A. Kratochwil, H. Fischer, M. Kansy, D. Zimmerli, E. M. Carreira and K. Müller, J. Med. Chem., 2015, 58, 9041; (e) A Meanwell, J. Med. Chem., 2011, 54, 2529.

9 (a) B. Zheng, S. V. D'Andrea, L.-Q. Sun, A. X. Wang, Y. Chen, P. Hrnciar, J. Friborg, P. Falk, D. Hernandez, F. Yu, A. K. Sheaffer, J. O. Knipe, K. Mosure, R. Rajamani, A. C. Good, K. Kish, J. Tredup, H. E. Klei, M. Paruchuri, A. Ng, Q. Gao, R. A. Rampulla, A. Mathur, N. A. Meanwell, F. McPhee and P. M. Scola, ACS Med. Chem. Lett., 2018, 9, 143; (b) T. Naret, J. Bignon, G. Bernadat, M. Benchekroun, H. Levaique, C. Lenoir J. Dubois, A. Pruvost, F. Saller, D. Borgel, B. Manoury, V. Leblais, R. Darrigrand, S. Apcher, J. D. Brion, E. Schmitt, F. R. Leroux, M. Alami and A. Hamze, Eur. J. Med. Chem., 2018 143, 473; (c) F. Narjes, K. F. Koehler, U. Koch, B. Gerlach, S. Colarusso, C. Steinkühler, M. Brunetti, S. Altamura, R. De Francesco and V. G. Matassa, Bioorg. Med. Chem. Lett. 2002, 12, 701; (d) S. Thompson, S. A. McMahon, J. H. Naismith and D. O'Hagan, Bioorg. Chem., 2016, 64, 37.

10 F. A. Momany, R. F. McGuire, A. W. Burgess and H. A Scheraga, J. Phys. Chem., 1975, 79, 2361.

11 (a) S. S. Zimmerman and H. A. Scheraga, Macromolecules, 1976, 9, 408; (b) D. E. Stewart, A. Sarkar and J. E. Wampler, J. Mol. Biol., 1990, 214, 253; (c) S. Fischer, R. L. Dunbrack and M. Karplus, J. Am. Chem. Soc., 1994, 116, 11931; (d) D. Kern, M. Schutkowski and T. Drakenberg, J. Am. Chem. Soc., 1997, 119, 8403.

12 (a) M. Levitt, J. Mol. Biol., 1981, 145, 251; (b) A. J. Salahuddin, J. Biosci., 1984, 6, 349; (c) W. J. Wedemeyer, E. Welker and H. A. Scheraga, Biochemistry, 2002, 41, 14637; (d) Mechanisms of Protein Folding, Ed. R. H. Pain, Oxford University Press, New York, 1994; (e) J. F. Brandts, H. R. Halvorson and M. Brennan, Biochemistry, 1975, 14, 4953; $(f)$ U. Reimer, G. Scherer, M. Drewello, S. Kruber, M.
Schutkowski and G. Fischer, J. Mol. Biol. 1998, 279 449 ; $(g$ P. A. M. Schmidpeter, J. R. Koch and F॰ X. Schmid Bioching Biophys. Acta, 2015, 1850, 1973; (h) W. J. Wedemeyer, E. Welker and H. A. Scheraga, Biochemistry, 2002, 41, 14637.

13 (a) P. Karoyan, S. Sagan, O. Lequin, J. Quancard, S. Lavielle and G. Chassaing, in Targets in Heterocyclic SystemsChemistry and Properties, O. A. Eds Attanasi, D. Spinelli, Royal Society of Chemistry, Cambridge, 2005, pp 216-273; (b) Cis-Trans Isomerization in Biochemistry, Ed. C. Dugave, Wiley-VCH, Weinheim, 2006; (c) C. Dugave and L. Demange, Chem. Rev., 2003, 103, 2475; (d) Y. Che and G. R. Marshall, Biopolymers, 2006, 81, 392.

14 (a) V. Kubyshkin, S. Pridma and N. Budisa, New J. Chem. 2018, 42, 13461 and refs cited; (b) N. A. Tolmachova, I. S. Kondratov, V. G. Dolovanyuk, S. O. Pridma, A. V. Chernykh, C. G. Daniliuc and G. Haufe, Chem. Commun., 2018, 54, 9683; (c) S. J. M. Verhoork, P. M. Killoran and C. R. Coxon, Biochemistry, 2018, 57, 6132; (d) M. Oliver, C. Gadais, J. García-Pindado, M. Teixidó, N. Lensen, G. Chaume and T. Brigaud, RSC Adv., 2018, 8, 14597; (e) C. Caupène, G. Chaume, L. Ricard and T. Brigaud, Org. Lett., 2009, 11, 209; (f) I. Jlalia, N. Lensen, G. Chaume, E. Dzhambazova, L. Astasidi, R. Hadjiolova, A. Bocheva and T. Brigaud, Eur. J. Med. Chem., 2013, 62, 122; (g) J. Simon, J. Pytkowicz, N. Lensen, G. Chaume and T. Brigaud, J. Org. Chem., 2016, 81, 5381; (h) H. Lubin, J. Pytkowicz, G. Chaume, G. Sizun-Thomé and T. Brigaud, J. Org. Chem., 2015, 80, 2700; (i) V. Kubyshkin, S. Afonin, S. Kara, N. Budisa, P. K. Mykhailiuk and A. S. Ulrich, Org. Biomol. Chem., 2015, 13, 3171; (j) I. S. Kondratov, V. G. Dolovanyuk, N. Tolmachova, I. I. Gerus, K. Bergander, R. Fröhlich and G. Haufe, Org. Biomol. Chem., 2012, 10, 8778; (k) N. G. Voznesenskaia, O. I. Shmatova, V. N. Khrustalev and V. G. Nenajdenko, Org. Biomol. Chem., 2018, 16, 7004; (I) J. Del Valle and M. Goodman, Angew. Chem., Int. Ed., 2002, 41, 1600; (m) X.-I. Qiu and F.-I. Qing, J. Org. Chem., 2002, 67, 7162.

15 (a) R. Nadano, Y. Iwai, T. Mori and J. Ichikawa, J. Org. Chem. 2006, 71, 8748; (b) X. L. Qiu and F. L. Qing, J. Org. Chem., 2003, 68, 3614; (c) R. C. McAtee, J. W. Beatty, C. C. McAtee and C. R. J. Stephenson, Org. Lett., 2018, 20, 3491.

16 (a) T. Wöhr and M. Mutter, Tetrahedron Lett., 1995, 36, 3847; (b) P. Dumy, M. Keller, D. E. Ryan, B. Rohwedder, T. Wöhr and M. Mutter, J. Am. Chem. Soc., 1997, 119, 91; (c) M. Keller, C. Sager, P. Dumy, M. Schutkowski, G. S. Fischer and M. Mutter, J. Am. Chem. Soc., 1998, 120, 2714.

17 (a) G. Chaume, O. Barbeau, P. Lesot and T. Brigaud, J. Org. Chem., 2010, 75, 4135; (b) G. Chaume, J. Simon, C. Caupene, N. Lensen, E. Miclet and T. Brigaud, J. Org. Chem., 2013, 78, 10144; (c) D. Feytens, G. Chaume, G. Chassaing, S. Lavielle, T. Brigaud, B. J. Byun, Y. K. Kang, E. Miclet, J. Phys. Chem. B, 2012, 116, 4069; (d) G. Chaume, D. Feytens, G. Chassaing, S. Lavielle, T. Brigaud and E. Miclet, New J. Chem., 2013, 37, 1336; (e) G. Chaume, J. Simon, N. Lensen, J. Pytkowicz, T. Brigaud and E. Miclet, J. Org. Chem., 2017, 82, 13602.

18 (a) E. Beausoleil and W. D. Lubell, J. Am. Chem. Soc., 1996, 118, 12902; (b) C. B. Braga, W. G. D. P. Silva and R. Rittner, New J. Chem. 2019, 43, 1757

19 For a recent example see R. Chingle, M. Mulumba, N. N. Chung, T. M.-D. Nguyen, H. Ong, S. Ballet, P. W. Schiller and W. D. Lubell, J. Org. Chem., 2019, 84, 6006 and cited references. 